\title{
Culturable fungi associated with wood decay of Picea abies in subalpine forest soils: a field-mesocosm case study
}

\author{
Claudia M Oliveira Longa ${ }^{(1)}$, \\ Davide Francioli ${ }^{(2)}$, \\ Maria Gómez-Brandón ${ }^{(3-4)}$, \\ Judith Ascher-Jenull (5-6), \\ Tommaso Bardelli ${ }^{(5-6)}$, \\ Giacomo Pietramellara ${ }^{(6)}$, \\ Markus Egli ${ }^{(7)}$, \\ Giacomo Sartori ${ }^{(8)}$, \\ Heribert Insam ${ }^{(5)}$
}

\begin{abstract}
Fungi are the principal wood decomposers in forest ecosystems and their activity provides wood necromass to other living organisms. However, the wood decay mechanisms and the associated microbial community are largely unknown, especially in Alpine areas. In this study, the culturable fraction of fungal communities associated with the decomposition of Norway spruce (Picea abies [L.] Karst) deadwood in subalpine forest soils were determined using microbiological methods coupled with molecular identification. Fungal communities were evaluated using in-field mesocosms after one year of exposition of $P$. abies wood blocks along an altitudinal gradient ranging from 1200 up to 2000 $\mathrm{m}$ a.s.l. comprising eight subalpine sites, four of them located at north- and other four at south-facing slopes. Although many saprotrophic species were isolated from the wood blocks, several white-rot species as the pathogenic fungi Armillaria cepistipes and Heterobasidion annosum, along with soft-rot fungi such as Lecytophora sp. were identified. Our results further indicated that the wood-inhabiting fungal community was mainly influenced by topographic features and by the chemical properties of the wood blocks, providing first insights into the effect of different slope exposure on the deadwood mycobiome in the subalpine forest ecosystem.
\end{abstract}

Keywords: Wood-inhabiting Fungi, Basidiomycota, Subalpine Forest, Wood Decomposition, Norway Spruce, Slope Exposure cay known as soft-rot includes several species belonging to mainly Ascomycota, which typically attack wood with a higher moisture content and preservative-treated wood (Rayner \& Boddy 1988). The rate of wood decomposition is influenced by the chemical properties and the cell structures of the wood, the nature and the abundance of the wood-decomposing organisms, as well as by different ecological and climatic factors (Rajala et al. 2012, Hiscox et al. 2016). In fact, the influence of slope ex-
(1) Department of Sustainable Agroecosystems and Bioresources, Research and Innovation Centre, Fondazione Edmund Mach, Via E. 1, 38010, San Michele all'Adige, Italy; (2) Plant Ecology and Nature Conservation Group, Wageningen University, P.O. Box 47, 6700AA Wageningen, The Netherlands; (3) Institute of Microbiology, University of Innsbruck, Technikerstraße 25d, 6020 Innsbruck, Austria; (4) Departamento de Ecología y Biología Animal, Universidad de Vigo, Vigo 36310, Spain; (5) Institute of Microbiology, University of Innsbruck, TechnikerstraBe 25d, 6020 Innsbruck, Austria; (6) Department of Agrifood and Environmental Science, University of Florence, Piazzale delle Cascine 18, 50144 Florence, Italy; (7) Department of Geography, University of Zürich, Winterthurerstrasse 190, 8057 Zürich, Switzerland; (8) Museo delle Scienze (MUSE), Corso del Lavoro e della Scienza 3, 38122 Trento, Italy

@ Claudia M Oliveira Longa (claudia.longa@fmach.it)

Received: May 09, 2018 - Accepted: Oct 01, 2018

Citation: Oliveira Longa CM, Francioli D, Gómez-Brandón M, Ascher-Jenull J, Bardelli T, Pietramellara G, Egli M, Sartori G, Insam H (2018). Culturable fungi associated with wood decay of Picea abies in subalpine forest soils: a field-mesocosm case study. iForest 11: 781785. - doi: 10.3832/ifor2846-011 [online 2018-11-28]

Communicated by: Alberto Santini posure on wood decay dynamics has recently been demonstrated in subalpine environments (Fravolini et al. 2016, Petrillo et al. 2016a, Petrillo et al. 2016b, Gómez-Brandón et al. 2017) and in subtropical and tropical forests (Geml et al. 2014, Purahong et al. 2017). However, it is so far unknown how exposure and, in general, climate affect the wood-inhabiting microbiota. In this context, we performed a study on the culturable wood-inhabiting fungi (WIF) in-field mesocosm experiment with the purpose of evaluating the fungal community colonizing Norway spruce (Picea abies [L.] Karst) deadwood after one year of exposition to natural conditions in subalpine forests.

\section{Material and methods}

The investigation area is located in Val di Rabbi in the south Alpine belt in northern Italy between a rather warm Insubrien and a cold Alpine climate. Eight sites along an altitudinal gradient ranging from 1200 up to $2000 \mathrm{~m}$ a.s.l. were investigated (Tab. S1 and Fig. S1 in the Supplementary material); four sites were positioned at north-facing slopes (N1-4) and other four at south-facing (S6-9) slopes (Egli et al. 2006, Bardelli et al. 2017). At each study site a field experiment using soil mesocosms was set up as described in Fravolini et al. (2016). Mesocosms (PVC tubes having diameter $=10.2$ $\mathrm{cm}$ and height $=25 \mathrm{~cm}$ ) were installed into the natural soil in August 2012, that is one year prior to the addition of the wood blocks of $P$. abies, at a distance of $>1 \mathrm{~m}$ 


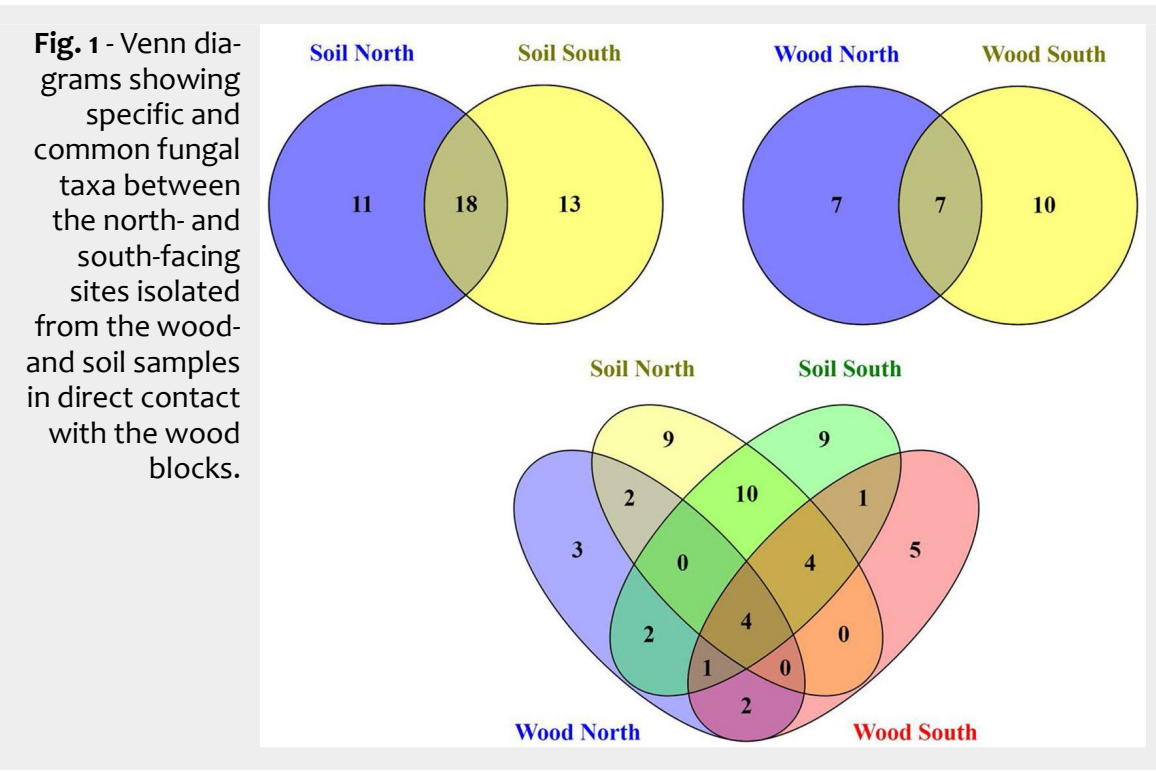

from large trees and $>0.5 \mathrm{~m}$ from the adjacent mesocosms, leaving at the surface a border of about $1 \mathrm{~cm}$. Wood blocks from the same $P$. abies tree and with a uniform size $(2 \times 5 \times 5 \mathrm{~cm})$ were placed on the soil surface in each of the mesocosm tubes. Three replicate mesocosms were installed in each of the eight study sites (Fig. S2 in the Supplementary material). P.abies wood samples and soil samples (0-5 cm depth) were collected from each mesocosm in June 2014, placed in polyethylene bags and transported on ice to the laboratory for

their physico-chemical characterization (Tab. S2 in the Supplementary material). Wood and soil physico-chemical properties were assessed as described by Fravolini et al. (2016) and Bardelli et al. (2017), respectively.

For the determination of the cultivable fungal decomposers all the wood blocks were surface sterilized by flaming and five small samples were cut out and placed on Petri dishes containing Hagem agar (HA) medium (Vasiliauskas \& Stenlid 1998) with addition of chloramphenicol (0.035 $\mathrm{g} \mathrm{L}^{-1}$,
Fig. 2 - 3D-Non metric multidimensional scaling (NMDS) ordination of a) soil (stress $=0.11)$ and b) wood (stress $=0.14$ ) fungal community structure at the north- and south-facing sites using the plot3d and ordigl functions in $\mathrm{R}$.

The NMDS ordination plots were fitted with the significant soil physicochemical and topographic factors using the envfit command in "vegan".

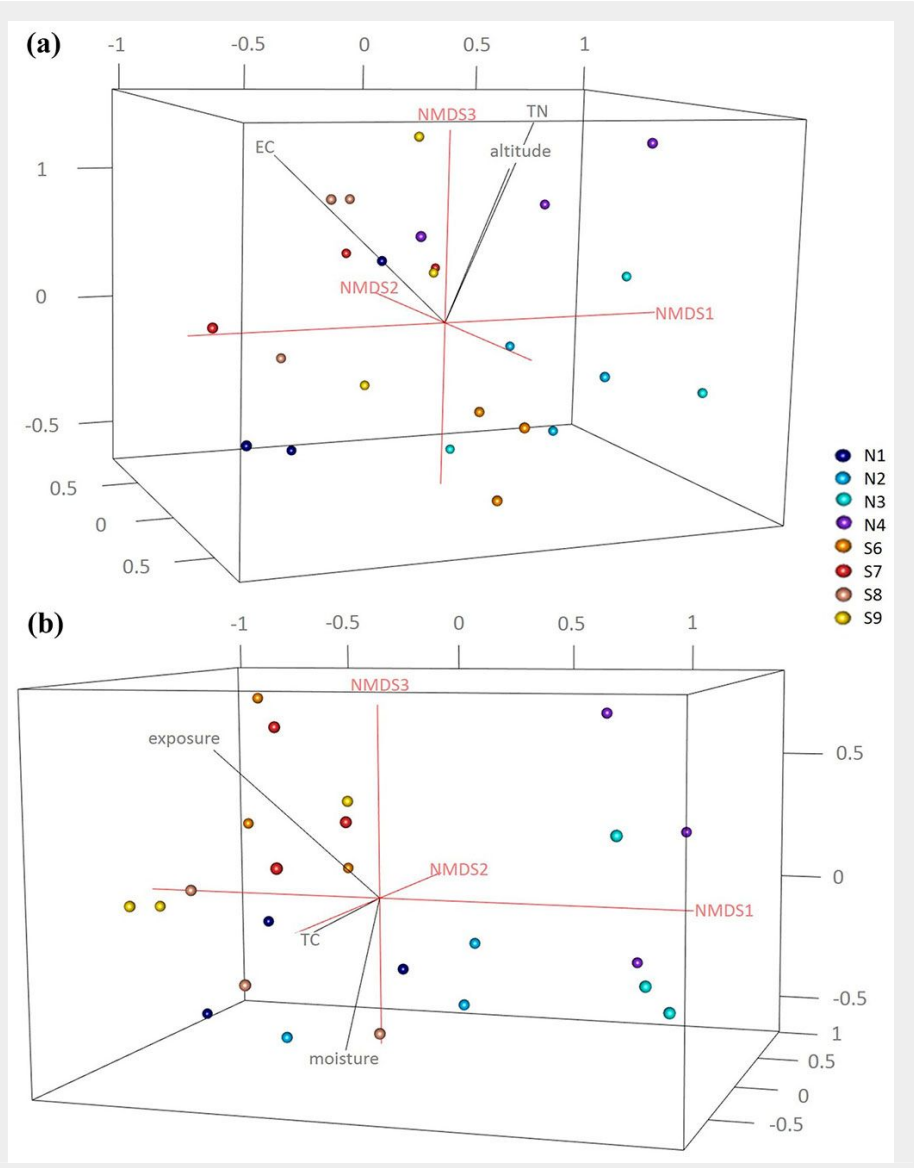

Sigma, MO, USA) and streptomycin (0.018 $\mathrm{g} \mathrm{L}^{-1}$, Sigma) in three replicates. All the inoculated plates were incubated at room temperature and continuously observed for 2 weeks. Soil samples were analysed by the Dilution Plate Technique: $10 \mathrm{~g}$ of soil were diluted with sterile water 1:10 (w/v) and mechanically shaken for $20 \mathrm{~min}$. The suspensions were further diluted 1:10 and $1 \mathrm{~mL}$ aliquots of the suspension 10-4 were homogeneously distributed and incubated at room temperature and continuously observed for 2 weeks. Fungal colonies were afterwards sub-cultured and the species in pure culture were identified based on classical morphological features using light microscopy. The fungal morphological identification was further confirmed by sequencing of the ITS2 region (Miller et al. 2016) using the ITS3 (5'-GCATCGATGAAGAACGCAGC-3') - ITS4 (5'-TCCTCCGCTTATTGATATGC3') primer pair (White et al. 1990) as described by Maresi et al. (2013). The ITS sequences were compared to those from the NCBI database (http://www.ncbi.nlm.nih. gov) to ascertain closest sequence matches. To visualize the WIF community compositions, we used three dimensional non-metric multidimensional scaling (3DNMDS) analysis based on the Bray-Curtis dissimilarity index calculated in $\mathrm{R}$ ( $\mathrm{R}$ Core Team 2015). Abiotic factors (including site, altitude and exposure) and chemical properties of the soil and deadwood were fitted to the NMDS ordination plots using the "envfit" function in the "vegan" package of $\mathrm{R}$, and goodness-of-fit statistics $\left(\mathrm{R}^{2}\right)$ were calculated with $P$ values based on 999 permutations (Oksanen 2013).

\section{Results and discussion}

In total 215 fungal isolates were cultured and 52 fungal taxa were morphologically identified and their identification was complemented by molecular analysis based on ITS sequences. The isolates on BLAST analyses showed $97-100 \%$ identity to the available sequences in NCBI (Tab. S3 and Fig. $S_{3}$ in Supplementary material). Overall, Ascomycota was the dominant phylum (32/52 taxa), followed by Zygomycota (11/52), Basidiomycota (8/52) and sterile mycelia. In particular, 42 taxa were isolated from the soil samples in direct contact with the wood blocks; 18 taxa were common to both slopes, while 11 taxa were exclusively isolated from north- and 13 taxa from south- facing sites (Fig. 1). The soil cultivable fungal population was mainly characterized by Ascomycota (26 taxa) and Zygomycota (10 taxa) with a lower proportion of Basidiomycota ( 5 taxa). Differences in community composition among the different sites were also observed (Fig. 1, Fig. $2 a$, Fig. 2b), and total nitrogen (TN), electrical conductivity (EC) and altitude correlated significantly with the soil fungal community composition (Tab. 1). From the wood blocks, a total of 24 fungal species were identified, of which 13 belong to Ascomycota, 6 to Zygomycota and 4 to Basid- 
iomycota, while for one isolate no match in the NCBI database was found (Tab. $\mathrm{S}_{3}$ in the Supplementary material). These results are in line with the study by Rajala et al. (2012) and Kazartsev et al. (2018), who reported that Ascomycota was the most dominant fungal phylum during the early stages of P. abies wood decay in boreal forests. Although Ascomycota are generally weak lignin decomposers, as the enzyme systems of most ascomycetes do not contain the typical lignin-modifying enzymes (with the exception of laccases), they may regulate the wood decomposition rate by interacting and competing with Basidiomycota in the early stage of decomposition (Mäkelä et al. 2015, Hoppe et al. 2016). Among the WIF isolated, 7 were common to both slopes, 7 were isolated only at the north-facing site and other 10 exclusively at the south-facing site (Fig. 1). These differences in community composition among the north- and southfacing sites $(R=0.31, p<0.05)$ were also reflected in the NMDS ordination plot (Fig. 2a, Fig. 2b) as the WIF clustered mainly as a function of slope exposure. Indeed, the WIF community composition correlated significantly with exposure, wood moisture and total carbon (TC), while lignin and cellulose contents did not contribute significantly in shaping the structure of WIF community (Tab. 1). Permutational Multivariate Analysis of Variance (PERMANOVA) confirmed that the soil and wood communities were significantly affected by altitude and exposure (Tab. 2). In line with our results, slope, elevation and wood physicochemical properties such as water content have been reported as determinant drivers for WIF richness and community composition in forest ecosystems (Rajala et al. 2012, Purahong et al. 2014, 2017, Hoppe et al. 2016, Gómez-Brandón et al. 2017). Parallel studies conducted on the same P. abies wood blocks (in-field mesocosm experiment) investigated in this work reported that the deadwood mass decay dynamics was related to wood $\mathrm{pH}$ and moisture, soil texture, temperature and topographic features including exposure and altitude (Fravolini et al. 2016, Gómez-Brandón et al. 2017), corroborating the considerable effect of abiotic and climatic factors on WIF community and consequently on $P$. abies deadwood degradation. Furthermore, about $60 \%$ of the WIF isolated from the wood blocks were also found in the top 5 $\mathrm{cm}$ soil layer, suggesting that soil biotic attributes are also important drivers of initial deadwood decay in sub-alpine Norway spruce forests. However, 10 taxa were isolated only from the wood samples, and among them, we identified several decay fungi commonly associated with wood decomposition such as Armillaria cepistipes (at sites S7 and S8), Bjerkandera adusta (at site S6) and Athelia decipiens and Heterobasidion annosum (at site N3). These fungi were also identified in a recent study on the WIF population associated with $P$. abies

Tab. 1 - Goodness-of-fit statistics $\left(R^{2}\right)$ for factors fitted to the three dimensional nonmetric multidimensional scaling (3D-NMDS) ordination of the soil and wood fungal community composition. The significance was based on 999 permutations. (nd): not detected; (EC): electrical conductivity; (TC): total carbon; (TN): total nitrogen; (Ptot): total phosphorous; (Pav): available phosphorous; $(*)$ : $\mathrm{P}<0.05 ;(* *): \mathrm{P}<0.01 ;(* * *)$ : $\mathrm{P}$ $<0.001$.

\begin{tabular}{lllll}
\hline \multirow{2}{*}{ Variable } & \multicolumn{2}{c}{ Soil } & \multicolumn{2}{c}{ Wood } \\
\cline { 2 - 5 } & $\mathbf{R}^{2}$ & $\mathbf{P}$ & $\mathbf{R}^{2}$ & $\mathbf{P}$ \\
\hline Exposure & 0.209 & 0.168 & 0.358 & $0.025^{*}$ \\
\hline Altitude & 0.305 & $0.045^{*}$ & 0.184 & 0.378 \\
\hline Moisture & 0.168 & 0.284 & 0.303 & $0.048^{*}$ \\
\hline Volatile solids & 0.199 & 0.218 & 0.095 & 0.585 \\
\hline $\mathrm{pH}$ & 0.136 & 0.389 & 0.018 & 0.943 \\
\hline $\mathrm{EC}$ & 0.410 & $0.013^{*}$ & 0.0210 & 0.924 \\
$\mathrm{TC}$ & 0.205 & 0.206 & 0.461 & $0.006^{* *}$ \\
\hline $\mathrm{TN}^{*}$ & 0.427 & $0.009^{* *}$ & $\mathrm{nd}$ & $\mathrm{nd}$ \\
\hline $\mathrm{NH}_{4}{ }^{-}$ & 0.248 & 0.116 & - & - \\
\hline $\mathrm{NO}_{3}{ }^{-}$ & 0.279 & 0.077 & - & - \\
\hline Ptot $_{\text {Pav }}$ & 0.089 & 0.617 & - & - \\
\hline Cellulose & 0.086 & 0.629 & - & - \\
\hline Lignin & - & - & 0.182 & 0.227 \\
\hline
\end{tabular}

deadwood using culture-independent molecular techniques on forest plots of the German Biodiversity Exploratories in southwestern Germany (Hoppe et al. 2016). Furthermore, these species represent necrotrophic and saprotrophic fungi including some of the most detrimental pathogens in conifer forests, which are capable of degrading wood, infecting the roots and stems and causing root white-rot (Keča \& Solheim 2011, Gori et al. 2013, Pramod et al. 2015). Lecytophora sp. and Humicola sp. were isolated from the wood blocks at site $\mathrm{N} 1$ and from soil at site S6, respectively, and species affiliated with these genera have already been associated with soft-rot decay of treated wood (Bugos et al. 1988). Interestingly, we found that three WIF taxa affiliated with the Trichoderma genus ( $T$. viridescens, T. atroviride, T. citrinoviride) were also isolated in a recent study on wood decay fungi across European forest ecosystems (Blaszczyk et al. 2016). Although they are frequently isolated in decaying wood and plant material (Longa et al. 2009), Trichoderma spp. are weak decomposers of non-decayed wood, but the delignification performed by white-rot fungi improves the accessibility of the woody material (Fukasawa et al. 2011). The basid-

Tab. 2 - PERMANOVA table showing differences in community composition (based on a Bray-Curtis dissimilarity matrix) among altitude and exposure, for the soil and wood fungal communities. (*): $\mathrm{P}<0.05 ;(* *): \mathrm{P}<0.01 ;(* * *)$ : $\mathrm{P}<0.001$.

\begin{tabular}{lclll}
\hline \multirow{2}{*}{ Variable } & \multicolumn{2}{c}{ Soil fungi } & \multicolumn{2}{c}{ Wood fungi } \\
\cline { 2 - 5 } & $\mathbf{R}^{2}$ & $\mathbf{P}$ & \multicolumn{1}{c}{$\mathbf{R}^{2}$} & $\mathbf{P}$ \\
\hline altitude & 0.18 & $0.001^{* * *}$ & 0.07 & $0.05^{*}$ \\
exposure & 0.06 & $0.05^{*}$ & 0.2 & $0.001^{* * *}$ \\
altitude : exposure & 0.11 & $0.01^{* *}$ & 0.12 & $0.01^{*}$ \\
\hline
\end{tabular}

iomycete Coprinellus radians was isolated from the wood blocks at sites S7 and S8 and from the soil samples at $\mathrm{N} 2$ and $\mathrm{S} 8$ and it has been hypothesized that Coprinoid species might have abilities of white-rot fungi on pre-decayed wood (Badalyan et al. 2011). Moreover, several saprotrophic ascomycetes species found in this study like Aspergillus sp., Penicillium sp., Cladosporium sp. and Epicoccum sp., along with members of the phylum Zygomycetes may influence the decay process in large woody debris, but in general they play a subordinate role as direct agents of wood decay (Stenlid et al. 2008) because they primarily utilize compounds derived from the action of wood degraders (Lindahl \& Olsson 2004).

In summary, the study of cultured fungi associated with the early stage of $P$. abies deadwood decay in subalpine forest soils resulted in a large number of species mainly belonging to the phyla Ascomycota and Zygomycota, which are generally saprotrophs with low impact as direct wood decay agents. Most of the isolates could be cold-adapted as they belong to species that are reported in periglacial soil at about $2500 \mathrm{~m}$ a.s.l. (Rodolfi et al. 2016). In fact, methods based on culturing are known to 
favor rapidly-growing fungi (like saprotrophs), and on the contrary, obliged plant pathogens or mutualistic biotrophic fungi such as ecto-mycorrhizal species are notoriously difficult or impossible to isolate (Bonito et al. 2016). However, several white-rot species affiliated with Basidiomycota - that have been previously associated with the decay process of deadwood in forest ecosystems - were isolated and identified with the cultivation method used in the present study. Some of these species were only isolated from wood blocks at particular sites, indicating that, besides deadwood chemical properties, altitude and exposure are important drivers for WIF community composition in subalpine forest ecosystems. A further step in the identification of the fungal taxa associated with deadwood decay processes would consist in a taxonomical characterization of the fungal community of the studied wood blocks using high-throughput next generation sequencing technologies.

\section{Acknowledgements}

M. Gómez-Brandón and J. Ascher-Jenull have been funded by the Fonds zur Förderung der wissenschaftlichen Forschung (FWF), Austria (Project 1989-B16) and partially by the Ente Cassa Risparmio di Firenze (Florence, Italy). M. Gómez-Brandón also acknowledges support by the Programa Ramón y Cajal (RYC-2016-21231; Ministerio de Economía y Competitividad, Spain). T. Bardelli has been funded by a PhD grant from the University of Florence (Italy) and by the Doctoral Scholarship Programme for Junior Researchers (2017/3/BIO-1) of the University of Innsbruck (Austria).

\section{References}

Badalyan SM, Szafranski K, Hoegger PJ, NavarroGonzález M, Majcherczyk A, Kües U (2011). New Armenian wood-associated coprinoid mushrooms: Coprinopsis strossmayeri and Coprinellus aff. radians. Diversity 3: 136-154. - doi: 10.3390/ d3010136

Bardelli T, Gómez-Brandón M, Ascher-Jenull J, Fornasier F, Arfaioli P, Francioli D, Egli M, Sartori G, Insam H, Pietramellara G (2017). Effects of slope exposure on soil physico-chemical and microbiological properties along an altitudinal climosequence in the Italian Alps. Science of the Total Environment 575: 1041-1055. - doi: 10.1016/j.scitotenv.2016.09.176

Blaszczyk L, Strakowska J, Chelkowski J, GabkaBuszek A, Kaczmarek J (2016). Trichoderma species occurring on wood with decay symptoms in mountain forests in Central Europe: genetic and enzymatic characterization. Journal of Applied Genetics 57: 397-407. - doi: 10.1007/ s13353-015-0326-1

Bonito G, Hameed K, Ventura R, Krishnan J, Schadt CW, Vilgalys R (2016). Isolating a functionally relevant guild of fungi from the root microbiome of Populus. Fungal Ecology 22: 3542. - doi: 10.1016/j.funeco.2016.04.007

Bugos RC, Sutherland JB, Adler JH (1988). Phenolic compound utilization by the soft rot fungus Lecythophora hoffmannii. Applied and Envi- ronmental Microbiology 54: 1882-1885. [online] URL: http://aem.asm.org/content/54/7/1882.sh ort

Egli M, Mirabella A, Sartori G, Zanelli R, Bischof S (2006). Effect of north and south exposure on weathering rates and clay mineral formation in Alpine soils. Catena 67: 155-174. - doi: 10.1016/j. catena.2006.02.010

Fravolini G, Egli M, Derungs C, Cherubini P, Ascher-Jenull J, Gómez-Brandón M, Bardelli T, Tognetti R, Lombardi F, Marchetti M (2016). Soil attributes and microclimate are important drivers of initial deadwood decay in sub-alpine Norway spruce forests. Science of the Total Environment 569- 570: 1064-1076. - doi: 10.1016/j.sci totenv.2016.06.167

Fukasawa Y, Osono T, Takeda H (2011). Wood decomposing abilities of diverse lignicolous fungi on nondecayed and decayed beech wood. Mycologia 103: 474-82. - doi: 10.3852/10-246

Geml J, Pastor N, Fernandez L, Pacheco S, Semenova TA, Becerra AG, Wicaksono CY, Nouhra ER (2014). Large-scale fungal diversity assessment in the Andean Yungas forests reveals strong community turnover among forest types along an altitudinal gradient. Molecular Ecology 23: 2452-2472. - doi: 10.1111/mec.12765

Gómez-Brandón M, Ascher-Jenull J, Bardelli T, Fornasier F, Fravolini G, Arfaioli P, Ceccherini MT, Pietramellara G, Lamorski K, Slawinski C, Bertoldi D, Egli M, Cherubini P, Insam H (2017). Physico-chemical and microbiological evidence of exposure effects on Picea abies - Coarse woody debris at different stages of decay. Forest Ecology and Management 391: 376-389. doi: 10.1016/j.foreco.2017.02.033

Gori Y, Cherubini P, Camin F, La Porta N (2013). Fungal root pathogen (Heterobasidion parviporum) increases drought stress in Norway spruce stand at low elevation in the Alps. European Journal of Forest Research 132: 607-619. doi: 10.1007/s10342-013-0698-x

Hiscox J, Clarkson G, Savoury M, Powell G, Savva I, Lloyd M, Shipcott J, Choimes A, Amargant Cumbriu XA, Boddy L (2016). Effects of precolonisation and temperature on interspecific fungal interactions in wood. Fungal Ecology 21: 32-42. - doi: 10.1016/j.funeco.2016.01.011

Hoppe B, Purahong W, Wubet T, Kahl T, Bauhus J, Arnstadt T, Hofrichter M, Buscot F, Krüger D (2016). Linking molecular deadwood-inhabiting fungal diversity and community dynamics to ecosystem functions and processes in Central European forests. Fungal Diversity 77: 367-379. doi: 10.1007/s13225-015-0341-x

Kazartsev I, Shorohova E, Kapitsa E, Kushnevskaya E (2018) Decaying Picea abies log bark hosts diverse fungal communities. Fungal Ecology 33: 1-12. - doi: 10.1016/j.funeco.2017.12.005 Keča N, Solheim H (2011). Ecology and distribution of Armillaria species in Norway. Forest Pathology 41: 120-132. - doi: 10.1111/j.1439-0329.20 10.00644. $\mathrm{x}$

Lindahl BD, Olsson S (2004). Fungal translocation - Creating and responding to environmental heterogeneity. Mycologist 18: 79-88. - doi: 10.1017/S0269915XO4002046

Longa CMO, Savazzini F, Tosi S, Elad Y, Pertot I (2009). Evaluating the survival and environmental fate of the biocontrol agent trichoderma atroviride $\mathrm{SC}_{1}$ in vineyards in northern
Italy. Journal of Applied Microbiology 106: 1549-1557. - doi: 10.1111/j.1365-2672.2008.04117.x Mäkelä MR, Marinović M, Nousiainen P, Liwanag AJM, Benoit I, Sipilä J, Hatakka A, De Vries RP, Hildén KS (2015). Aromatic metabolism of filamentous fungi in relation to the presence of aromatic compounds in plant biomass. Advances in Applied Microbiology 91: 63-137. - doi: 10.1016/bs.aambs.2014.12.001

Maresi G, Oliveira Longa CM, Turchetti T (2013). Brown rot on nuts of Castanea sativa Mill: an emerging disease and its causal agent. iForest 6: 294-301. - doi: 10.3832/iforo952-006

Miller KE, Hopkins K, Inward DJG, Vogler AP (2016). Metabarcoding of fungal communities associated with bark beetles. Ecology and Evolution 6: 1590-1600. - doi: 10.1002/ece3.1925 Oksanen J (2013). Multivariate analysis of ecological communities in R: vegan tutorial. R Doc 43. [online] URL: http://phylodiversity.net/azan ne/csfar/images/8/85/Vegan.pdf

Petrillo $M$, Cherubini P, Fravolini G, Marchetti $M$, Ascher-Jenull J, Schärer M, Synal HA, Bertoldi D, Camin F, Larcher R, Egli M (2016a). Time since death and decay rate constants of Norway spruce and European larch deadwood in subalpine forests determined using dendrochronology and radiocarbon dating. Biogeosciences 13: 1537-1552. - doi: 10.5194/bg-13-15372016

Petrillo M, Cherubini P, Sartori G, Abiven S, Ascher J, Bertoldi D, Camin F, Barbero A, Larcher R, Egli M (2016b). Decomposition of Norway spruce and European larch coarse woody debris (CWD) in relation to different elevation and exposure in an alpine setting. iForest 9: 154164. - doi: 10.3832/ifor1591-008

Pramod S, Koyani RD, Bhatt I, Vasava AM, Rao KS, Rajput KS (2015). Histological and ultrastructural alterations in the Ailanthus excelsa wood cell walls by Bjerkandera adusta (Willd.) P. Karst. International Biodeterioration and Biodegradation 100: 124-132. - doi: 10.1016/j.ibiod.20 15.02.026

Purahong W, Hoppe B, Kahl T, Schloter M, Schulze ED, Bauhus J, Buscot F, Krüger D (2014). Changes within a single land-use category alter microbial diversity and community structure: Molecular evidence from wood-inhabiting fungi in forest ecosystems. Journal of Environmental Management 139: 109-119. - doi: 10.1016/j.jenv man.2014.02.031

Purahong W, Pietsch KA, Lentendu G, Schöps R, Bruelheide $\mathrm{H}$, Wirth $\mathrm{C}$, Buscot F, Wubet $T$ (2017). Characterization of unexplored deadwood mycobiome in highly diverse subtropical forests using culture-independent molecular technique. Frontiers in Microbiology 8. - doi: 10.3389/fmicb.2017.00574

R Core Team (2015). R: a language and environment for statistical computing. R Foundation for Statistical Computing, Vienna, Austria. [online] URL: http://www.r-project.org

Rajala T, Peltoniemi M, Pennanen T, Mäkipää R (2012). Fungal community dynamics in relation to substrate quality of decaying Norway spruce (Picea abies [L.] Karst.) logs in boreal forests. FEMS Microbiology Ecology 81: 494-505. - doi: 10.1111/j.1574-6941.2012.01376.x

Rayner ADM, Boddy L (1988). Fungal decomposition of wood: its biology and ecology. John Wi- 
ley and Sons, Chichester, UK, pp. 116-144. [online] URL: http://www.cabdirect.org/cabdirect/ abstract/19911369864

Riley R, Salamov AA, Brown DW, Nagy LG, Floudas D, Held BW, Levasseur A, Lombard V, Morin $E$, Otillar R, Lindquist $E A$, Sun $H$, LaButti $K M$, Schmutz J, Jabbour D, Luo $H$, Baker SE, Pisabarro AG, Walton JD, Blanchette RA, Henrissat B, Martin F, Cullen D, Hibbett DS, Grigoriev IV (2014). Extensive sampling of basidiomycete genomes demonstrates inadequacy of the white-rot/brown-rot paradigm for wood decay fungi. Proceedings of the National Academy of Sciences USA 111: 9923-9928. - doi: 10.1073/ pnas.1400592111

Rodolfi M, Longa CMO, Pertot I, Tosi S, Savino E, Guglielminetti M, Altobelli E, Del Frate G, Picco AM (2016). Fungal biodiversity in the periglacial soil of Dosdè Glacier (Valtellina, Northern Italy). Journal of Basic Microbiology 56: 263-274. - doi: 10.1002/jobm.201500392

Speight MCD (1989). Saproxylic invertebrates and their conservation. Nature and Environment, Council of Europe, Strasbourg, France, pp. 78.

Stenlid J, Penttilä R, Dahlberg A (2008). Chapter
13 - Wood-decay basidiomycetes in boreal forests: distribution and community development. British Mycological Society Symposia Series 28: 239-262. - doi: 10.1016/S0275-0287(08)80015-X Vasiliauskas R, Stenlid J (1998). Fungi inhabiting stems of Picea abies in a managed stand in Lithuania. Forest Ecology and Management 109: 119-126. - doi: 10.1016/S0378-1127(98)00226-6 White TJ, Bruns T, Lee S, Taylor J (1990). Amplification and direct sequencing of fungal ribosomal RNA genes for phylogenetics. In: "PCR protocols: a guide to methods and applications" (Innis, MA, Gelfand DH, Sninsky JJ, White TJ eds). Academic Press, Inc., New York, USA, pp. 315-322. - doi: 10.1016/B978-0-12-372180-8.500421

WRB (1998). World reference base for soil resources. World Soil Resources Reports, vol. 84. FAO, Rome, Italy.

\section{Supplementary Material}

Tab. S1 - Characteristics of the eight study sites at north- and south-facing slopes (N14 and S6-9, respectively) in Val di Rabbi (Trentino, Italy).
Tab. S2 - Physico-chemical properties of soil and wood samples collected in July 2014 in the in-field mesocosm experiment.

Tab. S3 - Fungal taxa isolated from soil (So) and wood (W) along an altitudinal gradient in subalpine forest in Val di Rabbi (Trentino, Italy).

Fig. S1 - Overview of the study area (Trentino, Italy) with major vegetation units.

Fig. S2 - Example of the destructive in-field mesocosm sampling (wood and soil).

Fig. S3 - Number of fungal taxa identified for each site for the wood (a) and soil (b) samples $(n=3)$ along an altitudinal gradient in a subalpine forest in Val di Rabbi (Trentino, Italy).

Link: Oliveira_2846@supploo1.pdf 